\title{
Correction to: The Intensity of Lived-Experience in Martin Heidegger's Basic Problems of Phenomenology (WS 1919/1920): A Comparison to Being and Time
}

\section{Scott M. Campbell ${ }^{1}$}

Published online: 5 February 2020

(c) Springer Nature B.V. 2020

\section{Correction to: Human Studies (2019) 42:581-599 https://doi.org/10.1007/s10746-019-09523-5}

The original version of this article unfortunately contained a mistake. The title of the article published online 30 July 2019 reads:

"The Intensity of Lived-Experience in Martin Heidegger's Basic Problems of Phenomenology (WS 1919/2020): A Comparison to Being and Time"

The correct title reads:

"The Intensity of Lived-Experience in Martin Heidegger's Basic Problems of Phenomenology (WS 1919/1920): A Comparison to Being and Time"

Publisher's Note Springer Nature remains neutral with regard to jurisdictional claims in published maps and institutional affiliations.

The original article can be found online at https://doi.org/10.1007/s10746-019-09523-5.

\section{Scott M. Campbell}

scampbe8@naz.edu

1 Philosophy Department, Nazareth College, 4245 East Avenue, Rochester, NY 14618, USA 